\title{
Serum uric acid distribution according to SLC22A12 W258X genotype in a cross-sectional study of a general Japanese population
}

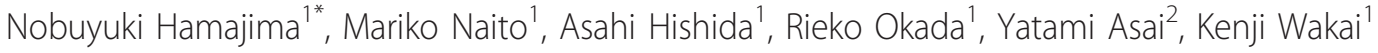

\begin{abstract}
Background: Although SLC22A12 258X allele was found among those with hypouricemia, it was unknown that serum uric acid distribution among those with SLC22A12 258X allele. This study examined serum uric acid (SUA) distribution according to SLC22A12 W258X genotype in a general Japanese population.

Methods: Subjects were 5,023 health checkup examinees (3,413 males and 1,610 females) aged 35 to 69 years with creatinine $<2.0 \mathrm{mg} / \mathrm{dL}$, who were participants of a cohort study belonging to the Japan Multi-Institutional Collaborative Cohort Study (J-MICC Study). SLC22A12 W258X was genotyped with a polymerase chain reaction with confronting two-pair primers.

Results: The genotype frequency was 4,793 for WW, 225 for WX, and 5 for XX, which was in Hardy-Weinberg equilibrium ( $p=0.164$ ) with $X$ allele 0.023 (95\% confidence interval [0.021-0.027]). Mean (range) SUA was 6.2 (2.111.4) $\mathrm{mg} / \mathrm{dL}$ for $W W, 3.9$ (0.8-7.8) $\mathrm{mg} / \mathrm{dL}$ for $W X$, and 0.8 (0.7-0.9) $\mathrm{mg} / \mathrm{dL}$ for $X X$ among males, and 4.5 (1.9-8.9) mg/ $\mathrm{dL}, 3.3(2.0-6.5) \mathrm{mg} / \mathrm{dL}$, and 0.60 (0.5-0.7) $\mathrm{mg} / \mathrm{dL}$ among females, respectively. Six individuals with SUA less than $1.0 \mathrm{mg} / \mathrm{dL}$ included two males with XX genotype, one male with $W X$ genotype, and three females with $X X$ genotype. Subjects with WX genotype were 14 (77.8\%) of 18 males with a SUA of 1.0-2.9 mg/dL, and 28 (34.6\%) of 81 females with the same range of SUA. The corresponding values were 131 (25.1\%) of 522 males and 37 (3.5\%) of 1,073 females for SUA 3.0-4.9 mg/dL, and 8 (0.4\%) of 2,069 males and 5 (1.1\%) of 429 females for SUA 5.0-6.9 mg/ $\mathrm{dL}$. The $X$ allele effect for SUA less than $3 \mathrm{mg} / \mathrm{dL}$ was significantly $(p<0.001)$ higher in males $(O R=102.5$, [33.9309.8]) than in females $(O R=25.6[14.4-45.3])$.
\end{abstract}

Conclusions: Although SLC22A12 W258X was a determining genetic factor on SUA, SUA of those with WX genotype distributed widely from $0.8 \mathrm{mg} / \mathrm{dL}$ to $7.8 \mathrm{mg} / \mathrm{dL}$. It indicated that other genetic traits and/or lifestyle affected SUA of those with WX genotype, as well as those with WW genotype.

\section{Background}

It is well known that the mean serum uric acid (SUA) is lower in females than in males. In addition, it is fully documented that age, menopause, food consumption, alcohol intake, obesity, a sedentary lifestyle, dyslipidemia, insulin resistance, blood pressure, renal function, and drug use for hypertension were associated with SUA levels [1-6]. Meanwhile, recent studies have elucidated that genotypes are also influential factors of SUA.

\footnotetext{
* Correspondence: nhamajim@med.nagoya-u.ac.jp

1 Department of Preventive Medicine, Nagoya University Graduate School of Medicine, Nagoya, Japan

Full list of author information is available at the end of the article
}

SUA is reabsorbed in renal tubules through uric acid transporter 1 (URAT1) encoded by $S L C 22 A 12$ in chromosome 11q13 $[7,8]$. SLC22A12 was documented to have functional polymorphisms, among which W258X was found among those with renal hypouricemia [9-11]. However, the distribution of SUA among those with $258 X$ allele was not reported in a general population. This study aimed to examine SUA distribution according to SLC22A12 W258X genotye, elucidating the overall effect of SLC22A12 W258X on SUA among Japanese.

\section{Methods}

This study was approved by the Ethics Committee of Nagoya University School of Medicine (approval

\section{Biomed Central}


number 288). Subjects who gave written informed consent to participate in the study were enrolled.

\section{Subjects and data collection}

Subjects were derived from 5,040 examinees aged 35-69 years who visited a health checkup center in Hamamatsu, Japan in 2006-2007. They were enrolled as participants of a cohort study belonging to the Japan Multi-Institutional Collaborative Cohort Study (J-MICC Study) [12,13]. As of October, 2010, one participant was found to be ineligible in terms of age (34 years old at enrollment), and 11 participants withdrew from the study. Blood sample was not available for one participant, and genotyping was not successful for another. Three participants with creatinine of $2.0 \mathrm{mg} / \mathrm{dL}$ or over were excluded from the analysis, leaving 5,023 subjects for the analysis.

Health checkup data including blood tests were used for this study. Peripheral blood was drawn in the morning from those fasting overnight. Biochemical analysis of the sampled sera was performed using an auto-analyzer in the health checkup center.

\section{Genotyping}

DNA was extracted from buffy coat conserved at $-80^{\circ} \mathrm{C}$ using a BioRobot ${ }^{\circledR}$ M48 (QIAGEN Group, Tokyo). SLC22A12 W258X polymorphism was genotyped by a polymerase chain reaction with confronting two-pair primers (PCR-CTPP) [14]. Each $25 \mu \mathrm{l}$ reaction tube contained 30-80 ng DNA, $0.12 \mathrm{mM}$ dNTP, $12.5 \mathrm{pmol}$ of each primer, $0.5 \mathrm{U}$ AmpliTaq Gold (Perkin-Elmer, Foster City, CA) and $2.5 \mu \mathrm{l}$ of 10x PCR buffer including $15 \mathrm{mM} \mathrm{MgCl}_{2}$. The PCR-CTPP was conducted with initial denaturation at $95^{\circ} \mathrm{C}$ for 10 minutes, 35 cycles of denaturation at $95^{\circ} \mathrm{C}$ for 1 minute, annealing at $62^{\circ} \mathrm{C}$ for 1 minute, and extension at $72^{\circ} \mathrm{C}$ for 1 minute, and a final extension at $72^{\circ} \mathrm{C}$ for 5 minutes. The primers were F1: 5'- TCC ATG CAG GCT CCA GG -3', R1: 5'- ACC ACC AGC TGC AGC AGT GTT -3', F2: 5' - TAC GGT GTG CGG GAC TGG -3', and R2: 5'- GGC AGG ATC TCC TCT GAG G -3'. The amplified DNA fragments were 117-base pairs (bp) for the $W$ allele ( $G$ allele), 176bp for the $X$ allele ( $A$ allele), and 255-bp for a common band, as demonstrated in Figure 1.

\section{Statistical analysis}

Body mass index (BMI) was calculated by weight $(\mathrm{kg}) /$ squared height $\left(\mathrm{m}^{2}\right)$. Hardy-Weinberg equilibrium was examined with a chi-square test. Binomial distribution was used to estimate $95 \%$ confidence interval (CI) of proportions. Means among the three genotype groups were tested with analysis of variance (ANOVA). Adjusted odds ratio (OR) and 95\% CI were estimated using an unconditional logistic model. All statistical

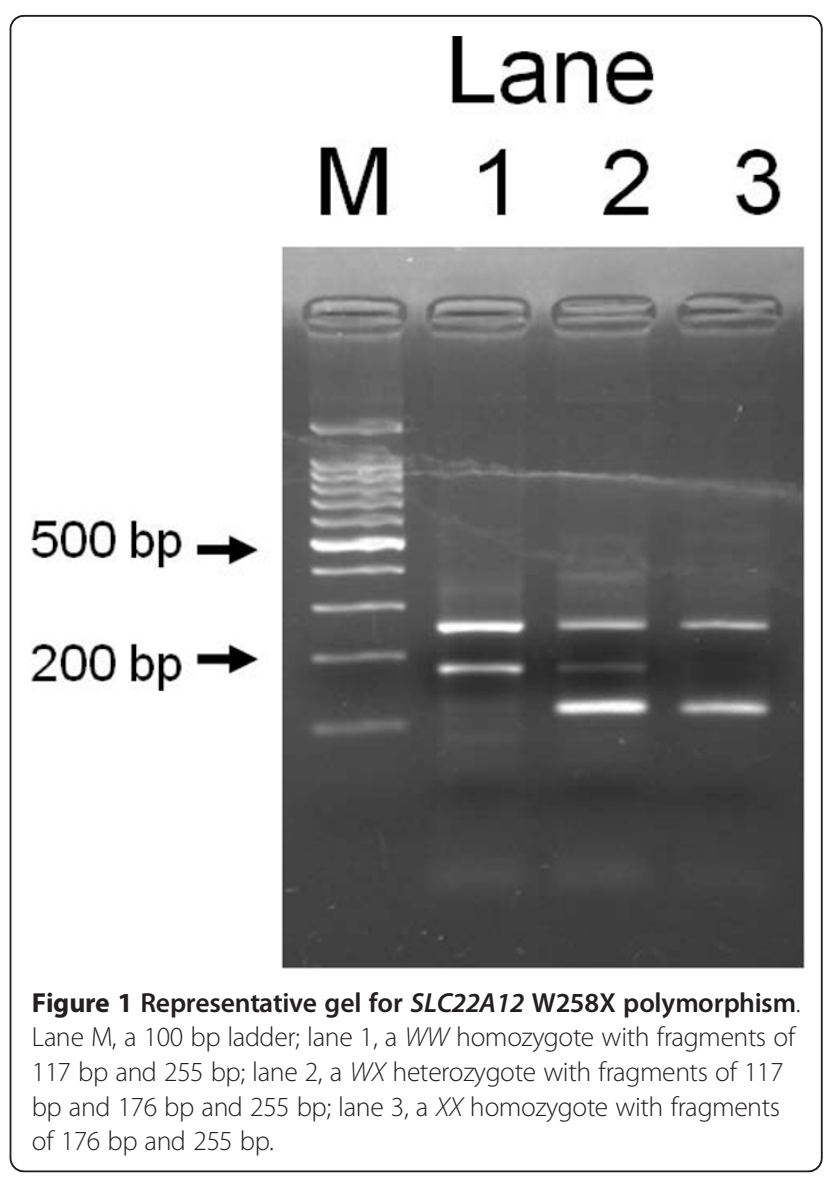

analyses were performed using STATA software version 11 (STATA, College Station, TX).

\section{Results}

Table 1 shows the characteristics of the 5,023 subjects (3,413 males and 1,610 females). Those with a SUA less than $3.0 \mathrm{mg} / \mathrm{dL}$ were $0.6 \%$ in males and $5.2 \%$ in females, while those with a SUA of $7.0 \mathrm{mg} / \mathrm{dL}$ or over were $23.5 \%$ in males and $1.5 \%$ in females. The genotype frequency was 4,793 for $W W, 225$ for $W X$, and 5 for $X X$, which was in Hardy-Weinberg equilibrium $(p=0.164)$; the $X$ allele frequency was 0.023 (95\% CI, 0.021-0.027).

The means of age, BMI, blood pressure, and blood tests according to the genotype and sex are listed in Table 2. The null hypothesis that the means were equal among the three genotypes was rejected with one-way ANOVA for creatinine and glucose in males, and for age and gamma-glutamyltransferase (GGT) in females. When the $W X$ and $X X$ were combined, the difference in the mean between the combined and the $W W$ became nonsignificant for GGT in females, but still significant for creatinine and glucose in males and age in females.

Mean SUA was $6.21 \mathrm{mg} / \mathrm{dL}$ for $W W, 3.95 \mathrm{mg} / \mathrm{dL}$ for $W X$, and $0.80 \mathrm{mg} / \mathrm{dL}$ for $X X$ among males, and $4.50 \mathrm{mg} / \mathrm{dL}$, 
Table 1 Characteristics of subjects according to sex

\begin{tabular}{|c|c|c|c|c|}
\hline \multirow[t]{2}{*}{ Characteristics } & \multicolumn{2}{|c|}{ Males } & \multicolumn{2}{|c|}{ Females } \\
\hline & $\mathrm{N}$ & (\%) & $\mathrm{N}$ & (\%) \\
\hline Total & 3,413 & $(100)$ & 1,610 & $(100)$ \\
\hline \multicolumn{5}{|l|}{ Age (years) } \\
\hline $35-39$ & 265 & (7.8) & 192 & (11.9) \\
\hline $40-49$ & 983 & $(28.8)$ & 495 & (30.7) \\
\hline $50-59$ & 1,366 & $(40.0)$ & 630 & (39.1) \\
\hline $60-69$ & 799 & $(23.4)$ & 293 & (18.2) \\
\hline \multicolumn{5}{|l|}{ SUA (mg/dL) } \\
\hline-3.0 & 21 & $(0.6)$ & 84 & $(5.2)$ \\
\hline $3.0-4.9$ & 522 & $(15.3)$ & 1,073 & (66.6) \\
\hline $5.0-6.9$ & 2,069 & $(60.6)$ & 429 & (26.6) \\
\hline $7.0-$ & 801 & $(23.5)$ & 24 & $(1.5)$ \\
\hline \multicolumn{5}{|l|}{ BMI $\left(\mathrm{kg} / \mathrm{m}^{2}\right)^{*}$} \\
\hline-18.4 & 90 & $(2.6)$ & 160 & (9.9) \\
\hline $18.5-24.9$ & 2,423 & $(71.0)$ & 1,195 & (74.2) \\
\hline $25.0-$ & 899 & $(26.3)$ & 255 & (15.8) \\
\hline \multicolumn{5}{|c|}{ Creatinine $(\mathrm{mg} / \mathrm{dL})$} \\
\hline 0.0-0.4 & 0 & $(0.0)$ & 33 & $(2.1)$ \\
\hline $0.5-0.9$ & 2,710 & $(79.4)$ & 1,574 & (97.8) \\
\hline $1.0-1.4$ & 701 & $(20.5)$ & 3 & $(0.2)$ \\
\hline $1.5-1.9$ & 2 & $(0.1)$ & 0 & $(0.0)$ \\
\hline \multicolumn{5}{|l|}{ SLC22A12 W258X } \\
\hline WW & 3,256 & $(95.4)$ & 1,537 & (95.5) \\
\hline$w X$ & 155 & (4.5) & 70 & $(4.3)$ \\
\hline$X X$ & 2 & $(0.1)$ & 3 & $(0.2)$ \\
\hline
\end{tabular}

SUA, serum uric acid; BMI, body mass index.

*BMI was not available for one male.

$3.31 \mathrm{mg} / \mathrm{dL}$, and $0.60 \mathrm{mg} / \mathrm{dL}$ among females, respectively. The difference in mean SUA between $W X$ and $W W$ genotypes was significantly $(\mathrm{p}=8 \mathrm{E}-12)$ higher in males $(2.26 \mathrm{mg} / \mathrm{dL})$ than in females $(1.19 \mathrm{mg} / \mathrm{dL})$. The difference among three genotypes was highly significant both in males $(\mathrm{p}<1 \mathrm{E}-40)$ and females $(\mathrm{p}=1 \mathrm{E}-33)$. Table 3 demonstates the SUA distribution in percentage according to the genotype. All five individuals with $X X$ genotype had a SUA of less than $1.0 \mathrm{mg} / \mathrm{dL}$; the range was $0.7 \mathrm{mg} / \mathrm{dL}$ to $0.9 \mathrm{mg} / \mathrm{dL}$ in males and $0.5 \mathrm{mg} / \mathrm{dL}$ to $0.7 \mathrm{mg} / \mathrm{dL}$ in females. The SUA of those with $W X$ genotype varied from $0.8 \mathrm{mg} / \mathrm{dL}$ to 7.8 $\mathrm{mg} / \mathrm{dL}$ in males and from $2.0 \mathrm{mg} / \mathrm{dL}$ to $6.5 \mathrm{mg} / \mathrm{dL}$ in females, while the corresponding values for those with $W W$ genotype were $2.1 \mathrm{mg} / \mathrm{dL}$ to $11.4 \mathrm{mg} / \mathrm{dL}$ in males and 1.9 $\mathrm{mg} / \mathrm{dL}$ to $8.9 \mathrm{mg} / \mathrm{dL}$ in females. Subjects with $W X$ genotype were 14 (77.8\%) of 18 males with SUA $1.0-2.9 \mathrm{mg} / \mathrm{dL}$, and $28(34.6 \%)$ of 81 females with the same range of SUA. The corresponding values were 131 (25.1\%) of 522 males and 37 (3.5\%) of 1,073 females for SUA $3.0-4.9 \mathrm{mg} / \mathrm{dL}$, and 8 $(0.4 \%)$ of 2,069 males and $5(1.1 \%)$ of 429 females for SUA $5.0-6.9 \mathrm{mg} / \mathrm{dL}$, as depicted in Figure 2.

The age-adjusted OR $(95 \% \mathrm{CI})$ of SUA $<3 \mathrm{mg} / \mathrm{dL}$ for the $X$ allele was significantly $(\mathrm{p}<0.001)$ higher in males $(\mathrm{OR}=102.5,95 \% \mathrm{CI}, 33.9-309.8)$ than in females $(\mathrm{OR}=$ 25.6, 95\% CI, 14.4-45.3). The corresponding ORs were reduced for $\mathrm{SUA}<4 \mathrm{mg} / \mathrm{dL}$, as shown in Table 4 . Among those with BMI $<25 \mathrm{~kg} / \mathrm{m}^{2}$, the age-adjusted OR (95\% CI) was $116.3(32.5-416.8)$ in 2,514 males and $23.3(12.7-42.9)$ in 1,355 females, while they were 78.6 (8.4-731.5) in 899 males with BMI $>25 \mathrm{~kg} / \mathrm{m}^{2}$ and 56.2 (9.9-320.4) in 255 females with BMI $>25 \mathrm{~kg} / \mathrm{m}^{2}$. When these ORs were adjusted for creatinine and glucose in males and for GGT in females, no substantial differences were observed; for example, the OR of SUA < $3 \mathrm{mg} / \mathrm{dL}$ for $X$ allele was 89.8 instead of 102.5 in males and 30.7 instead of 25.6 in females.

\section{Discussion}

This study demonstrated the SUA distribution according to $S L C 22 A 12$ W258X genotype in a general Japanese

Table 2 Characteristics of subjects according to SLC22A12 W258X genotype

\begin{tabular}{|c|c|c|c|c|c|c|c|c|}
\hline \multirow[t]{2}{*}{ Characteristics } & \multicolumn{4}{|c|}{ Males } & \multicolumn{4}{|c|}{ Females } \\
\hline & $\begin{array}{c}W W \\
\mathrm{n}=3,256\end{array}$ & $\begin{array}{c}W X \\
\mathrm{n}=155\end{array}$ & $\begin{array}{c}X X \\
\mathrm{n}=2\end{array}$ & $\mathbf{P}$ & $\begin{array}{c}W W \\
\mathrm{n}=1,537\end{array}$ & $\begin{array}{c}W X \\
\mathrm{n}=70\end{array}$ & $\begin{array}{c}X X \\
\mathrm{n}=3\end{array}$ & $\mathrm{p}$ \\
\hline Age (years) & 50.6 & 52.0 & 52.5 & 0.166 & 49.1 & 51.4 & 58.3 & 0.017 \\
\hline Body mass index $\left(\mathrm{kg} / \mathrm{m}^{2}\right)$ & 23.5 & 23.7 & 20.9 & 0.240 & 22.0 & 21.9 & 19.7 & 0.407 \\
\hline Systolic blood pressure (mmHg) & 121.0 & 120.5 & 105.0 & 0.319 & 114.4 & 115.1 & 119.3 & 0.811 \\
\hline Diastolic blood pressure $(\mathrm{mmHg})$ & 76.3 & 76.0 & 66.0 & 0.350 & 69.9 & 70.4 & 66.7 & 0.798 \\
\hline Total cholesterol (mg/dL) & 202.3 & 202.7 & 195.5 & 0.944 & 207.2 & 208.9 & 197.3 & 0.793 \\
\hline HDL cholesterol (mg/dL) & 57.7 & 56.0 & 63.5 & 0.338 & 71.1 & 69.7 & 88.3 & 0.159 \\
\hline Triglyceride (mg/dL) & 124.7 & 129.0 & 66.0 & 0.460 & 85.1 & 85.2 & 73.3 & 0.895 \\
\hline $\mathrm{AST}(\mathrm{U} / \mathrm{dL})$ & 22.4 & 22.4 & 18.0 & 0.890 & 19.5 & 20.5 & 27.0 & 0.071 \\
\hline ALT (U/L) & 25.5 & 26.6 & 18.5 & 0.732 & 17.1 & 19.5 & 24.7 & 0.066 \\
\hline GGT (U/L) & 47.0 & 45.9 & 24.5 & 0.817 & 23.2 & 25.0 & 56.3 & 0.023 \\
\hline Creatinine (mg/dL) & 0.86 & 0.82 & 0.90 & $0.001^{*}$ & 0.61 & 0.62 & 0.63 & 0.750 \\
\hline Blood urea nitrogen (mg/dL) & 14.3 & 14.5 & 16.0 & 0.567 & 13.1 & 14.0 & 15.0 & 0.057 \\
\hline Blood glucose (mg/dL) & 101.9 & 107.0 & 90.5 & $0.003^{*}$ & 93.7 & 95.2 & 89.7 & 0.434 \\
\hline
\end{tabular}

$\mathrm{HDL}$, high-density lipoprotein; AST, aspartate aminotransferase; ALT, alanine aminotransferase; GGT, gamma-glutamyltransferase. $p$-value was calculated from one-way analysis of variance among $W W, W X$, and $X X$ genotypes. 
Table 3 Serum uric acid (SUA) distribution (\%) according to SLC22A12 W258X among Japanese health checkup examinees

\begin{tabular}{|c|c|c|c|c|c|c|c|c|c|c|c|c|c|}
\hline \multirow[t]{2}{*}{ Genotype } & \multirow[t]{2}{*}{$\mathrm{N}$} & \multicolumn{12}{|c|}{ SUA (mg/dL) } \\
\hline & & $0.0-0.9$ & $1.0-1.9$ & $2.0-2.9$ & $3.0-3.9$ & $4.0-4.9$ & $5.0-5.9$ & $6.0-6.9$ & 7.0-7.9 & $8.0-8.9$ & $9.0-$ & Mean & S.D. \\
\hline \multicolumn{14}{|l|}{ Males } \\
\hline WW & 3,256 & 0.0 & 0.0 & 0.1 & 1.6 & 10.4 & 31.4 & 31.9 & 17.4 & 6.1 & 1.0 & 6.21 & 1,12 \\
\hline$W X$ & 155 & 0.6 & 0.0 & 9.0 & 40.0 & 44.5 & 3.2 & 1.9 & 0.6 & 0.0 & 0.0 & 3.95 & 0.83 \\
\hline$x X$ & 2 & 100.0 & 0.0 & 0.0 & 0.0 & 0.0 & 0.0 & 0.0 & 0.0 & 0.0 & 0.0 & 0.80 & 0.14 \\
\hline Total & 3,413 & 0.1 & 0.0 & 0.5 & 3.3 & 12.0 & 30.1 & 30.5 & 16.7 & 5.9 & 0.9 & 6.10 & 1.21 \\
\hline \multicolumn{14}{|l|}{ Females } \\
\hline WW & 1,537 & 0.0 & 0.1 & 3.4 & 24.9 & 42.5 & 22.8 & 4.7 & 1.2 & 0.3 & 0.0 & 4.50 & 0.94 \\
\hline$w X$ & 70 & 0.0 & 0.0 & 40.0 & 38.6 & 14.3 & 5.6 & 1.4 & 0.0 & 0.0 & 0.0 & 3.31 & 0.89 \\
\hline$X X$ & 3 & 100.0 & 0.0 & 0.0 & 0.0 & 0.0 & 0.0 & 0.0 & 0.0 & 0.0 & 0.0 & 0.60 & 0.10 \\
\hline Total & 1,610 & 0.2 & 0.1 & 5.0 & 25.5 & 41.2 & 22.0 & 4.6 & 1.2 & 0.3 & 0.0 & 4.44 & 0.98 \\
\hline
\end{tabular}

*95\% Cl: 95\% confidence interval for SUA mean.

population. The SUA of all five subjects with $X X$ genotype was less than $1 \mathrm{mg} / \mathrm{dL}$, while SUA of those with $W X$ genotype distributed widely; from $0.8 \mathrm{mg} / \mathrm{dL}$ to $7.8 \mathrm{mg} / \mathrm{dL}$ in males and from $2.0 \mathrm{mg} / \mathrm{dL}$ to $6.5 \mathrm{mg} / \mathrm{dL}$ in females. The difference in the mean SUA between
$W X$ and $W W$ genotypes was $2.26 \mathrm{mg} / \mathrm{dL}$ in males and $1.19 \mathrm{mg} / \mathrm{dL}$ in females, indicating that the reduction of the mean SUA due to possessing $X$ allele was significantly larger in males than in females. Since the distribution among the males with $W X$ genotype was closer

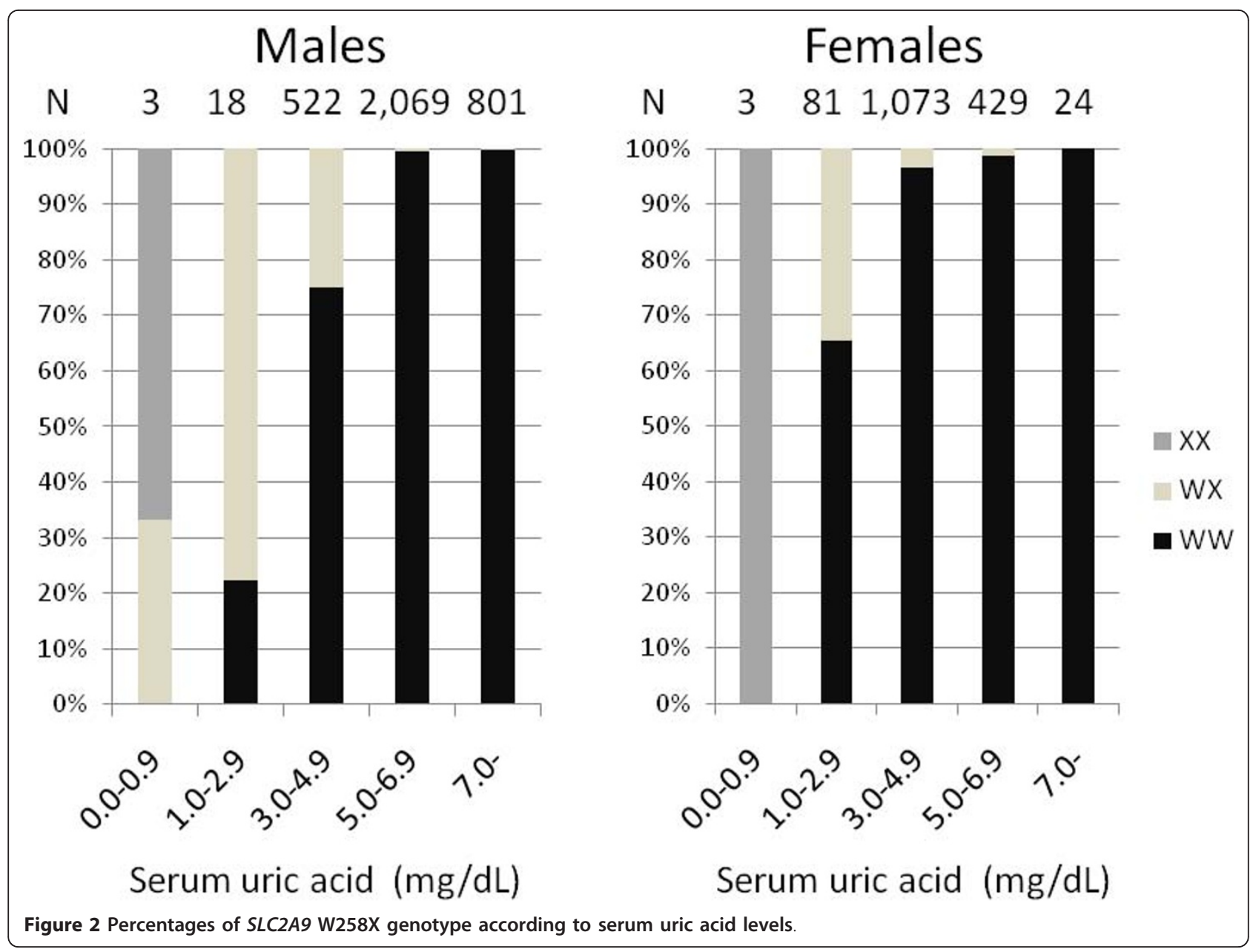


Table 4 Odds ratio (OR) and 95\% confidence interval (95\% Cl) of low serum uric acid (SUA) for SLC22A12 W258X among Japanese health checkup examinees

\begin{tabular}{|c|c|c|c|c|c|c|c|c|}
\hline \multirow[b]{2}{*}{ Genotype } & \multicolumn{4}{|c|}{ SUA $<3 \mathrm{mg} / \mathrm{dL}$} & \multicolumn{4}{|c|}{ SUA $<4 \mathrm{mg} / \mathrm{dL}$} \\
\hline & $<3 \mathrm{mg} / \mathrm{dL}$ & $3 \mathrm{mg} / \mathrm{dL} \leq$ & OR & $95 \% \mathrm{Cl}$ & $<4 \mathrm{mg} / \mathrm{dL}$ & $4 \mathrm{mg} / \mathrm{dL} \leq$ & OR & $95 \% \mathrm{Cl}$ \\
\hline \multicolumn{9}{|l|}{ Males } \\
\hline WW & 4 & 3,252 & 1 & Reference & 55 & 3,201 & 1 & Reference \\
\hline$W X$ or $X X$ & 17 & 140 & 102.5 & $33.9-309.8$ & 79 & 78 & 58.2 & $38.6-87.9$ \\
\hline Total & 21 & 3,392 & & & 157 & 3,279 & & \\
\hline \multicolumn{9}{|l|}{ Females } \\
\hline WW & 53 & 1,484 & 1 & Reference & 436 & 1,101 & 1 & Reference \\
\hline$W X$ or $X X$ & 31 & 42 & 25.6 & $14.4-45.3$ & 58 & 15 & 11.9 & $6.6-21.5$ \\
\hline Total & 84 & 1,526 & & & 494 & 1,116 & & \\
\hline \multicolumn{9}{|l|}{ Both sexes } \\
\hline Males with WW & 4 & 3,252 & 1 & Reference & 55 & 3,201 & 1 & Reference \\
\hline Males with $W X$ or $X X$ & 17 & 140 & 106.5 & $35.3-321.6$ & 79 & 78 & 63.7 & $42.0-96.5$ \\
\hline Females with WW & 53 & 1,484 & 27.2 & 9.8-75.4 & 436 & 1,101 & 22.4 & $16.8-29.9$ \\
\hline Females with $W X$ or $X X$ & 31 & 42 & 672.6 & $225.4-2006.8$ & 58 & 15 & 246.3 & 130.9-363.7 \\
\hline Interaction* & & & 0.23 & $0.07-0.80$ & & & 0.17 & $0.08-0.35$ \\
\hline Total & 105 & 4,918 & & & 628 & 4,395 & & \\
\hline
\end{tabular}

*Interaction between females and $X$ allele for low SUA.

to that among the females with $W W$ genotype (Table 3 ), the effect of $X$ allele on SUA was similar to the effect of sex difference. BMI did not significantly modify the effect of the $X$ allele on SUA both for males and females. These findings were actually new for the associations between SLC22A12 W258X and SUA.

Among Japanese, the frequency of $258 X$ allele was 0.024 among 1,875 participants of a cohort study [11], 0.023 among 980 controls in a case-control study [15], and 0.025 among 5,165 participants from another cohort study [16], which were quite similar to the estimate in the present study (0.023). Among Koreans, $258 \mathrm{X}$ allele was found in 3 of 5 hypouricemia patients [17], and was $1.1 \%$ in a general population [18]. Since this allele has not been reported among other ethnic groups to date, the origin was thought to be in East Asia [19].

Several genotypes affecting SUA have been reported to date. ABCG2 in chromosome 4q22 coding ATP-binding cassette subfamily $\mathrm{G}$ member 2 has functional polymorphisms, Q126X (rs72552713) and Q141K (rs2231142), with a minor allele frequency of 0.018 and 0.281 in Japanese, respectively [20]. Although the genotypes with reduced function increase the risk of hyperuricemia [20-22], $126 \mathrm{X}$ was rare and $141 \mathrm{~K}$ was less influential on SUA. SLC2A9 in chromosome 4p16p15.3 coding glucose transporter 9 (GLUT9) was reported to have mutations (R380W and R198C in Japanese [23], L75R in an Israeli-Arab family, and exon 7 deletion in AshkenaziJewish [24]) causing hypouricemia. Their allele frequency was very rare. Common polymorphisms including MTHFR C677T have been reported to have an association with SUA
$[25,26]$, but the impact was limited in comparison with the above genotypes. Accordingly, SLC22A12 258X seemed to be one of the important genetic traits influencing SUA among Japanese.

The present study discovered that the $X$ allele had a significantly larger impact in males than in females. The OR of possessing the $X$ allele was larger in males than in females; 102.5 vs 25.6 for SUA $<3 \mathrm{mg} / \mathrm{dL}$ and 58.2 vs 11.9 for SUA $<4 \mathrm{mg} / \mathrm{dL}$. The differences in mean SUA between males and females were $0.20 \mathrm{mg} / \mathrm{dL}$ among those with $X X$ genotype, $0.63 \mathrm{mg} / \mathrm{dL}$ among those with $W X$ genotype, and $1.71 \mathrm{mg} / \mathrm{dL}$ among those with $W W$ genotype. There was no biological explanation for these phenomena.

In the present study, since the subjects with $X X$ genotype were few, the distriubtion of those with $X X$ genotype might not reflect the distribution of the population with $X X$ genotype. Another limitation was that the medication influencing SUA was not taken into account for the genotype frequency according to the SUA level. Since the medication was common for hyperuricemia, but not for hypouricemia, the effect due to the medication might be limited for low SUA.

\section{Conclusions}

In conclusion, this study demonstrated the SUA distribution according to SLC22A12 W258X genotype in a large study. The effect of $X$ allele was larger in males than in females. Since the $X$ allele was influential and relatively common among Japanese, the information on the genotype would be useful for the interpretation of individual SUA. Since SUA distributes widely among Japanese with $W X$ 
genotype, further studies are warranted to elucidate the determinants of the SUA distribution among those with $W X$ genotype, as well as among those with $W W$ genotype.

\section{List of abbreviations}

BMI: body mass index; bp: base pairs; Cl: confidence interval; GLUT9: glucose transporter 9; OR: odds ratio; PCR-CTPP: polymerase chain reaction with confronting two-pair primers; SUA: serum uric acid; URAT1: uric acid transporter 1.

\section{Acknowledgements}

This study was supported in part by a Grant-in-Aid for Scientific Research on Special Priority Areas of Cancer from the Japanese Ministry of Education, Culture, Sports, Science and Technology. We are grateful to Ms Yoko Mitsuda and Ms Keiko Shibata for their technical assistance.

\section{Author details}

${ }^{1}$ Department of Preventive Medicine, Nagoya University Graduate School of Medicine, Nagoya, Japan. ${ }^{2}$ Seirei Social Welfare Community, Hamamatsu, Japan.

\section{Authors' contributions}

$\mathrm{NH}$ conceived of the study, participated in the design and coordination, and drafted the manuscript. MN and KW participated in the design and coordination, edited the data, and drafted the manuscript. RO contributed the genotyping, establishing PCR primers and PCR conditions for SLC22A12 W258X. AH and YA participated in the coordination, organizing the informed consent process and data/sample collection. All authors read and approved the final manuscript.

\section{Competing interests}

The authors declare that they have no competing interests.

Received: 11 November 2010 Accepted: 2 March 2011

Published: 2 March 2011

\section{References}

1. Burack RC, Keller JB, Higgins MW: Cardiovascular risk factors and obesity: are baseline levels of blood pressure, glucose, cholesterol and uric acid elevated prior to weight gain? J Chronic Dis 1985, 38:865-872.

2. Benedek TG: Correlations of serum uric acid and lipid concentrations in normal, gouty, and atherosclerotic men. Ann Intern Med 1967, 66:851-861.

3. Alderman M: Uric acid in hypertension and cardiovascular disease. Can J Cardiol 1999, 15(Suppl F):20F-22F.

4. Bengtsson C, Tibblin E: Serum uric acid levels in women an epidemiological survey with special reference to women with high serum uric acid values. Acta Med Scand 1974, 196:93-102.

5. Rathmann W, Funkhouser E, Dyer AR, Roseman JM: Relations of hyperuricemia with the various components of the insulin resistance syndrome in young black and white adults: the CARDIA study. Coronary Artery Risk Development in Young Adults. Ann Epidemiol 1998, 8:250-261.

6. Nakashima M, Uematsu T, Kosuge K, Kanamaru M: Pilot study of the uricosuric effect of DuP-753, a new angiotensin II receptor antagonist, in healthy subjects. Eur J Clin Pharmacol 1992, 42:333-335.

7. Taniguchi A, Kamatani N: Control of renal uric acid excretion and gout. Curr Opin Rheumatol 2008, 20:192-197.

8. Enomoto A, Kimura $\mathrm{H}$, Chairoungdua A, Shigeta $\mathrm{Y}$, Jutabha $\mathrm{P}$, Cha SH, Hosoyamada M, Takeda M, Sekine T, Igarashi T, Matsuo H, Kikuchi Y, Oda T, Ichida K, Hosoya T, Shimokata K, Niwa T, Kanai Y, Endou H: Molecular identification of a renal urate-anion exchanger that regulates blood urate levels. Nature 2002, 417:447-452.

9. Komoda F, Sekine T, Inatomi J, Enomoto A, Endou H, Ota T, Matsuyama T, Ogata T, Ikeda M, Awazu M, Muroya K, Kamimaki I, Igarashi T: W258X mutation in SLC22A12 is the predominant cause of Japanese renal hypouricemia. Pediatr Nephrol 2004, 19:728-733.

10. Ichida K, Hosoyamada M, Hisatome I, Enomoto A, Hikita M, Endou H, Hosoya T: Clinical and molecular analysis of patients with renal hypouricemia in Japan- influence of URAT1 gene on urinary urate excretion. J Am Soc Nephrol 2004, 15:164-173.
11. Iwai N, Mino Y, Hosoyamada M, Tago N, Kokubo Y, Endou H: A high prevalence of renal hypouricemia caused by inactive SLC22A12 in Japanese. Kidney Int 2004, 66:935-944.

12. Hamajima N, J-MICC Study Group: The Japan Multi-institutional Collaborative Cohort Study (J-MICC Study) to detect gene-environment interactions for cancer. Asian Pac J Cancer Prev 2007, 8:317-323.

13. Asai $Y$, Naito M, Suzuki M, Tomoda A, Kuwabara M, Fukada Y, Okamoto A, Oishi S, Ikeda K, Nakamura T, Misu Y, Katase S, Tokumasu S, Nishio K, Ishida Y, Hishida A, Morita E, Kawai S, Okada R, Wakai K, Tamakoshi A, Hamajima N: Baseline data of Shizuoka area in the Japan Multiinstitutional Collaborative Cohort Study (J-MICC Study). Nagoya J Med Sci 2009, 71:137-144.

14. Hamajima N, Saito T, Matsuo K, Kozaki K, Takahashi T, Tajima K: Polymerase chain reaction with confronting two-pair primers for polymorphism genotyping. Jpn J Cancer Res 2000, 91:865-868.

15. Taniguchi A, Urano W, Yamanaka M, Yamanaka H, Hosoyamada M, Endou $\mathrm{H}$, Kamatani $\mathrm{N}$ : A common mutation in an organic anion transporter gene, SLC22A12, is a suppressing factor for the development of gout. Arthritis Rheum 2005, 52:2576-2577.

16. Tabara Y, Kohara K, Kawamoto R, Hiura Y, Nishimura K, Morisaki T, Kokubo Y, Okamura T, Tomoike H, Iwai N, Miki T: Association of four genetic loci with uric acid levels and reduced renal function: the J-SHIPP Suita Study. Am J Nephrol 2010, 32:279-286.

17. Cheong HI, Kang JH, Lee JH, Ha IS, Kim S, Komoda F, Sekine T, Igarashi T, Choi Y: Mutational analysis of idiopathic renal hypouricemia in Korea. Pediatr Nephrol 2005, 20:886-890.

18. Lee $\mathrm{H}$, Choi HJ, Lee BH, Kang HK, Chin HJ, Yoon HJ, Ha IS, Kim S, Choi Y, Cheong HI: Prevalence of hypouricaemia and SLC22A12 mutations in healthy Korean subjects. Nephrology 2008, 13:661-666.

19. Ichida K, Hosoyamada M, Kamatani N, Kamitsuji S, Hisatome I, Shibasaki T, Hosoya T: Age and origin of the G774A mutation in SLC22A12 causing renal hypouricemia in Japanese. Clin Genet 2008, 74:243-251.

20. Matsuo H, Takada T, Ichida K, Nakamura T, Nakayama A, Ikebuchi Y, Ito K, Kusanagi Y, Chiba T, Tadokoro S, Takada Y, Oikawa Y, Inoue H, Suzuki K, Okada R, Nishiyama J, Domoto H, Watanabe S, Fujita M, Morimoto Y, Naito M, Nishio K, Hishida A, Wakai K, Asai Y, Niwa K, Kamakura K, Nonoyama S, Sakurai Y, Hosoya T, Kanai Y, Suzuki H, Hamajima N, Shinomiya N: Common defects of ABCG2, a high-capacity urate exporter, cause gout: a functional-based genetic analysis in a Japanese population. Sci Transl Med 2009, 1:5ra11.

21. Woodward O, Kottgen A, Coresh J, Boerwinkle E, Guggino WB, Köttgen M: Identification of a urate transporter, $A B C G 2$, with a common functional polymorphism causing gout. PNAS 2009, 106:10338-10342.

22. Yamagishi $K$, Tanigawa T, Kitamura A, Köttgen A, Folsom AR, Iso H, CIRCS Investigators: The rs2231142 variant of the $A B C G 2$ gene is associated with uric acid levels and gout among Japanese people. Rheumatology 2010, 49:1461-1465.

23. Matsuo H, Chiba T, Nagamori S, Nakayama A, Domoto H, Phetdee K, Wiriyasermkul P, Kikuchi Y, Oda T, Nishiyama J, Nakamura T, Morimoto Y, Kamakura K, Sakurai Y, Nonoyama S, Kanai Y, Shinomiya N: Mutations in glucose transporter 9 gene SLC2A9 cause renal hypouricemia. Am J Hum Genet 2008, 83:744-751.

24. Dinour D, Gray NK, Campbell S, Shu X, Sawyer L, Richardson W, Rechavi G, Amariglio N, Ganon L, Sela BA, Bahat H, Goldman M, Weissgarten J, Millar MR, Wright AF, Holtzman EJ: Homozygous SLC2A9 mutations cause severe renal hypouricemia. J Am Soc Nephrol 2010, 21:64-72.

25. Golbahar J, Aminzadeh MA, Al-Shboul QM, Kassab S, Rezaian GR: Association of methylenetetrahydrofolate reductase (C677T) polymorphism with hyperuricemia. Nutr Metab Cardiovasc Dis 2007, 17:462-467.

26. Itou S, Goto Y, Suzuki K, Kawai S, Naito M, Ito Y, Hamajima N: Significant association between methylentetrahydrofolate reductase 677T allele and hyperuricemia among adult Japanese subjects. Nutr Res 2009, 29:710-715.

\section{Pre-publication history}

The pre-publication history for this paper can be accessed here: http://www.biomedcentral.com/1471-2350/12/33/prepub

doi:10.1186/1471-2350-12-33

Cite this article as: Hamajima et al:: Serum uric acid distribution according to SLC22A12 W258X genotype in a cross-sectional study of a general Japanese population. BMC Medical Genetics 2011 12:33. 